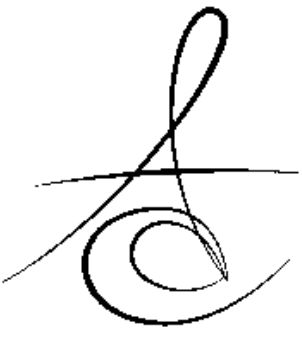

Makale Kodu/Article code: 2571

Makale Gönderilme tarihi; 26.01.2016

Kabul Tarihi: 27.09.2016

\section{YENİ TİP 1 DİABETES MELLİTUS TEŞHİSİ KONULAN ÇOCUKLARIN BESLENME VE AĞIZ HİJYENİ EĞíTIMMİNİN DEĞERLENDİRİLMESİ}

\author{
EVALUATION OF ORAL HYGIENE AND NUTRITIONAL EDUCATION OF \\ CHILDREN WITH NEWLY DIAGNOSED TYPE 1 DIABETES MELLITUS
}

\author{
Dr. Dt. Cüneyt Asım ARAL*
}

Doç. Dr. Korcan DEMİR**

\section{öz}

Amaç: Literatürde tip 1 diyabetin erken döneminde verilen beslenme ve ağız hijyeni eğitiminin sonuçlarını değerlendiren çalışma bulunmamaktadır. Bu çalışmanın amacı Tip 1 Diabetes Mellitus (T1DM) teşhisi konulan çocuklarda beslenme ve ağız hijyeni alışkanlıklarını incelemek, aynı yaş grubu sistemik sağlıklı kontrollerle karşılaştırmak ve bulguları diyabetin kontrolünün 3 . ayında tekrar değerlendirmektir.

Gereç ve Yöntem: Çalışmamıza $10-16$ yaş arası 60 birey dâhil edildi. Yaş, boy, kilo ve vücut kütle indeksi açısından benzer olan çalışma gruplarımızı; sistemik olarak sağlıklı bireyler (S), yeni T1DM teşhisi konulan hastalar (DY) ve T1DM'li hastaların 3. ay kontrolleri (DK) oluşturdu. Bireylerin periodontal muayenelerinde OHİ-S (Oral Hijyen İndeksi) ve SKI (Sulkus Kanama İndeksi) belirlendi. Çalışmaya katılan bireylerin ebeveynleri ile beslenme ve ağız hijyeni anketi yapıldı.

Bulgular: DY grubunda OHİ-S değerleri, DK grubuna göre daha yüksekti $(p=0.005)$. DY grubunda SKİ değerleri, S ile DK gruplarından daha fazla bulundu (Sırasıyla; $p=0.002$ ve $p=0.015$ ). Öğün atlamayan bireylerin yüzdesi DK grubunda en yüksekti (\%90). DY grubunda; genellikle tatlı tüketen bireylerin yüzdesi (\%66.7) ve genellikle içecek tüketen bireylerin yüzdesi (\%76.7) en yüksekti. S grubunda genellikle atıştırmalık tüketen bireylerin yüzdesi en düşüktü(\%26.7). Genellikle dişlerini fırçalayan ve düzenli gargara yapan bireylerin yüzdeleri DY grubuna göre (Sırasıyla; \%30, $\% 10)$, DK grubunda (Sırasıyla; \%76.7, \%46.7) yükseldiği izlendi. DY grubunda fırçalama esnasında genellikle dişeti kanaması olan bireylerin yüzdesi (\%53.3), S (\%26.7) ve DK (\%23.3) gruplarına göre daha fazla bulundu.

Sonuçlar: Ağız hijyenini de etkileyebilen beslenme alışkanlıkları, kontrolsüz T1DM'li çocuklarda bozulduğu izlendi. Dolayısı ile diyabetik bireylere verilen ağız hijyeni ve beslenme eğitimi; hem diyabetin kontrolü, hem de periodontal sağığın idamesi için önemlidir.

Anahtar Kelimeler: Tip 1 Diabetes Mellitus; ağız hijyeni; beslenme alışkanlıkları.

\section{ABSTRACT}

Objectives: There is no study in the literature evaluating the results of oral hygiene and nutritional education in the early stages of type 1 diabetes. The aim of this study was to evaluate oral hygiene and nutritional education in children diagnosed with Type 1 Diabetes Mellitus (T1DM), and reevaluate the children diagnosed with T1DM after 3 months, and compare them with those of systemically healthy controls.

Materials and Methods: The present study was consisted of 60 individuals aged between 10-16 years. Systemically healthy individuals (S), patients with newly diagnosed T1DM (DY), and their control after 3 months (DK), formed the study groups which were similar with regards to age, height, weight, and body mass index. The periodontal examination was consisted of OHI-S (Oral Hygiene Index) and SBI (Sulcus Bleeding Index). Oral hygiene and nutritional questionnaire was conducted with the parents.

Results: OHI-S values were higher in group DY, compared to group DK $(p=0.005)$. SBI values in group DY were higher compared to group $S$ and group DK ( $p=0.002$ and $p=0.015$, respectively). No meal skipping percentage in group DK was the highest (90\%). The percentages of usually sweet $(66.7 \%)$ and drink consumption $(76.7 \%)$ were the highest in the group DY. The percentage of usually snack consumption was the lowest in group S (26.7\%). The percentages of usually tooth brushing and gargling increased in group DK $(76.7 \%$ and $46.7 \%$, respectively), compared to group DY (30\% and $10 \%$, respectively). The percentage of bleeding on brushing in group DY (53.3\%) was higher compared to group S (26.7\%) and group DK (23.3\%).

Conclusions: Dietary habits, which can effect oral hygiene, is disrupted in children with uncontrolled T1DM. Oral hygiene and nutritional education of individuals with diabetes is important for both control of diabetes and maintenance of periodontal health.

Key Words: Type 1 Diabetes Mellitus; oral hygiene; dietary habits

\footnotetext{
* Malatya Ağız ve Diş Sağlığı Hastanesi, Periodontoloji Uzmanı

** Dokuz Eylül Üniversitesi, Tıp Fakültesi, Nevvar-Salih İşgören Çocuk Hastanesi, Çocuk Endokrinolojisi Bilim Dalı
} 


\section{GİRİ̧̧}

Diabetes Mellitus, insülin sekresyonu ve/veya insülinin etki mekanizmasında görülen bozukluklar nedeniyle ortaya çıkan hiperglisemi ile karakterize sistemik metabolik hastalığa verilen genel isimdir. Tip 1 Diabetes Mellitus (T1DM), insülin salgılayan pankreasın $\beta$-hücrelerinin otoimmün yıkımı sonucu insülin yetmezliği ile karakterize iken, Tip 2 Diabetes Mellitus (T2DM) ise insülin moleküllerindeki defektten veya insülin eksikliğinden ziyade insülinin hücre reseptörlerindeki değişikliğe bağı olarak insülin fonksiyonundaki bozukluklardan kaynaklanır. Diyabetik olguların \%2025 'ini oluşturan tip 1 diyabet temel olarak çocukluk yaşlarında ortaya çıkarken, tip 2 diyabet genellikle orta ve ileri yaş hastalığıdır. ${ }^{1}$

CDC'nin (Centers for Disease Control and Prevention) 2010 veri tabanına göre ABD'de toplumun \%8.3 ünü oluşturan yaklaşık 25.8 milyon bireyin Diabetes Mellitus'tan etkilendiği ve bunların \%27' sinin teşhisi konulmamış, kontrolsüz vakalardan oluştuğu götserilmiştir. ${ }^{2}$ Global bir sağlık problemi olan Diabetes Mellitus, vücuttaki tüm sistemleri etkileyen kronik metabolik bir hastalıktır. Periodontal dokular da metabolizmadaki değişikliklerden etkilenmektedir. Kontrolsüz Diabetes Mellitus'un periodontal doku kaybını şiddetlendirdiği bilinmektedir. ${ }^{3}$ Deneysel çalışmalar, diyabete bağlı görülen periodontal doku kaybına neden olabilecek bazı mekanizmalardan söz etmektedir. Diyabetin inflamatuar yanıtı uzatarak şiddetini artırdığı, ${ }^{4}$ monosit ve makrofajlarının fonksiyonlarını değiştirerek periodontal patojenlere karşı daha fazla sitokin sentezine sebep olduğu ${ }^{5}$ ve alveolar kemiğin turnoverını etkilediği ${ }^{6}$ gösterilmiştir. Özet olarak kontrolsüz diyabette görülen tüm bu değişiklikler, diyabetin varlığında görülen periodontal doku kaybında artışa neden olmaktadır.

Kronik periodontitis, primer etyolojik ajanın mikrobiyal dental plak olduğu ve genellikle semptomsuz ilerleyen, dolayısı ile teşhisi gecikebilen bir inflamatuar hastalıktır.,8 Periodontal hastalığın en yaygın klinik semptomu olan dişeti kanaması, hastayı hekime getiren bir bulgudur. Diyabetli bireylerde dişeti kanaması 6 yaş gibi erken yaşta bile izlenebilmektedir ve diyabetik hastaların periodontal sağlığının izlenmesinde ve ağız hijyeninin değerlendirilmesinde en önemli parametrelerden birisidir. ${ }^{9-13}$ Tip 1 diyabetli çocuklarda zayıf oral hijyenin periodontal kemik kaybıyla ilişkilendirilebileceği belirtilmiştir. ${ }^{14}$ Ağız hijyeninin ve plak birikiminin, sadece fırçalama yeteneği ve alışkanlığı ile değil, beslenme alışkanlıkları ile de ilişkili olduğu gösterilmiştir. ${ }^{15,16}$ Doğru beslenme alışkanlıklarının diyabet gelişme riskini yarı yarıya düşürdüğü ve diyabetli bireylerde ilaç tedavisinin etkinliğini artırdığı bilinmektedir. ${ }^{17}$ Dolayısı ile beslenme alışkanlıkları ve ağız hijyeni, özellikle diyabetik bireylerde hem metabolik kontrolün sağlanması için, hem de periodontal sağlığı korumak için önemlidir.

Literatürde diyabetli bireylere verilen beslenme, egzersiz ve ağız hijyeni eğitiminin etkisini değerlendiren çalışma bulunmamaktadır. Çalışmamızda 10-16 yaş arası yeni tip 1 diyabet teşhisi konulmuş bireylerde; beslenme, egzersiz ve ağız hijyeni anketi alışkanlıklarının aynı yaş grubu sistemik sağlıklı bireyler ile karşılaştırılması ve 3. ay kontrolde alışkanlıkların tekrar değerlendirmesi amaçlandı.

\section{GEREÇ VE YÖNTEM}

\section{Çalışma Grupları}

Çalışmamıza 10-16 yaş arası toplam 60 birey dâhil edildi. Çalışma gruplarımızı; sistemik olarak sağlıklı bireyler $(S)(n=30)$, yeni T1DM teşhisi konulan hastalar (DY) $(n=30)$ ve yeni teşhis T1DM'li hastaların 3 ay sonrası kontrolleri (DK) $(n=30)$ oluşturmaktaydı.

S grubunda; 18 erkek ve $12 \mathrm{kIz}$, DY grubunda ise 17 erkek, $13 \mathrm{kIz}$ birey bulunmaktaydı. S grubunun yaş ortalaması $10.56 \pm 0.96$ yıl iken; DY grubunun yaş ortalaması $11.31 \pm 2.81$ yıl olarak hesaplandı. S grubunun Vücut Kitle İndeksi (VKİ) $17.65 \pm 2.26$ iken; DY grubunun VKİ $18.72 \pm 4.58$ olarak hesaplandı.

Tip 1 diyabeti olan çalışma grupları, Dr. Behçet Uz Çocuk Hastalıkları ve Cerrahisi Eğitim ve Araştırma Hastanesi'ne, sistemik sağlıklı kontrol grubu ise Şifa Üniversitesi Diş Hekimliği Fakültesi Pedodonti / Periodontoloji Anabilim Dalları'na tedavi amacı ile başvuran gönüllü bireylerden oluşturuldu.

Projemiz kapsamında yeni T1DM teşhisi konuIan 52 bireyin muayenesi gerçekleştirildi. Çalışmamız prospektif bir araştırma olduğundan, kontrollerine gelmeyen ve kontrol zamanına çeşitli sebepler ile uymayan bireyler çalışma dışı bırakıldı. Anketlerine tutarsız cevap veren hastalar çalışmadan çıkartıldı. Ayrıca T1DM hariç herhangi bir sistemik hastalığı bulunan ve çalışmamız boyunca çalışmamızın sonuçlarını etkileyebilecek antibiyotik gibi ilaç kullanan hastalar çalışmaya dâhil edilmedi.

Çalışmamıza başlamadan önce yerel Klinik Araştırmalar Etik Kurulu tarafından etik kurul izni alındı 
(B.30.2.ŞFÜ.00.50.500\83). Araştırmaya dâhil edilen tüm hastalara ve 18 yaşını doldurmamış olan bireylerin velilerine, Helsinki Bildirgesi'ne uygun olarak hazırlanan bilgilendirilmiş onam formu imzalatıldı. Çalışmamız Helsinki Hayvan ve İnsan Araştırmaları Uygulama Prensipleri'ne uyumlu olarak yürütüldü.

\section{Diabetes Mellitus'un Tanı Kriterleri}

Diabetes Mellitus tanısı, Çocuk Endokrinolojisi uzmanları tarafından konuldu. Tanının konulmasında diyabet semptomları ve biyokimyasal değerler esas alındı. Tanı konulurken aşağıda belirtilen testlerden herhangi biri veya birkaçının sonucunun pozitif çıkması durumu değerlendirildi. Tip 1 Diabetes Mellitus'un semptomları ile birlikte günün herhangi bir saatinde en son öğünden geçen zamana bakılmaksızın ölçülen plazma glikoz düzeyinin $\geq 200 \mathrm{mg} / \mathrm{dl}(11,1 \mathrm{mmol} / \mathrm{l})$ çıkması ve açlık plazma glikoz seviyesi (en az 8 saatlik tam açlık sonrası) $\geq 126 \mathrm{mg} / \mathrm{dl}(7,0 \mathrm{mmol} / \mathrm{l})$ olması incelendi. Bu kriterlere uyan bireylere tip 1 diyabet teşhisi konuldu ve takip eden günlerde testler tekrarlanarak teşhis doğrulandı.

\section{Çalışmadan Çıkartılma Kriterleri}

Tip 1 Diabetes Mellitus hariç başka bir sistemik hastalığı bulunan, son 3 ay içerisinde sistemik antibiyotik tedavisi, dental veya periodontal tedavi almış olan veya düzenli ilaç kullanan (antiinflamatuar, antidepresanlar gibi) hastalar çalışma dışında bırakıldı.

\section{Muayeneleri}

Bireylerin Genel, Dental ve Periodontal

Yaş, cinsiyet, genel sağlık durumu ve düzenli ilaç kullanımı, boy, kilo ve vücut kütle indeksleri (BMI) kaydedildi. Bireylerin ağız hijyenlerinin değerlendirilmesinde, basitleştirilmiş OHI-S (Oral Hijyen İndeksiSimplified) kullanıldı. OHI-S; Debris İndeksi (DI-S) ve Kalkulus İndeksi (CI-S) olarak iki alt kategoride incelenmektedir. ${ }^{13}$ Ayrıca bireylerin periodontal muayenelerinde; SKI (Sulkus Kanama İndeksi) indeksine bakıldı. ${ }^{18}$

Çalışmamızda diyabet teşhisi konulan hastalara ve ebeveynlerine diyabet ile periodontal hastalığın yakın ilişkisi anlatıldı ve oral hijyen eğitimi verildi, ayrıca hastanede yattıkları süre boyunca gerekli periodontal tedavileri tamamlandı. Sistemik olarak sağlıklı gruba da gerekli periodontal tedavi uygulanmasına rağmen 3. ayda tekrar periodontal muayene yapılmadı ve çalışmamızda verileri sunulmadı.

\section{İstatistiksel Analizler}

Sayısal verilerin gruplar arası kıyaslamalarında independent veya paired student-t testi kullanıldı. No- minal ve ordinal verilerin analizinde $x 2$ testi kullanıldı. $p<0.05$ istatistiksel anlamlılık derecesi olarak kabul edildi.

\section{SONUÇLAR}

Yaş ve VKİ değerleri açısından gruplar arasında istatistiksel anlamlı fark izlenmedi ( $p>0.05$ ). OHİ-S, Dİ-S ve Kİ-S değerleri açısından, $S$ grubu ile DY grubu arasında istatistiksel anlamlı fark bulundu (Sırasıyla; $\mathrm{p}$ $=0.107, p=0.075, p=0.122$ ). Ayrıca, DY grubu ile DK grubu arasında ise istatistiksel anlamlı fark izlendi (Sırasıyla; $p=0.0050, p=0.0013, p=0.0001$ ). SKİ değerleri açısından, $\mathrm{S}$ grubu ile DY grubu arasında ve DY grubu ile DK grubu arasında istatistiksel anlamlı fark bulundu (Sırasıyla; $p=0.002, p=0.015$ ) (Tablo 1).

Tablo 1. Gruplara Göre Periodontal Verilerin Dağılımı

\begin{tabular}{cccc}
\hline & $\begin{array}{c}\text { Sağlıklı } \\
\text { Kontrol } \\
(\mathbf{S})\end{array}$ & $\begin{array}{c}\text { T1DM Yeni } \\
\text { Teşhis } \\
\text { (DY) }\end{array}$ & $\begin{array}{c}\text { T1DM } \\
\text { Kontrol } \\
\text { (DK) }\end{array}$ \\
\hline OHİ-S & $1.10 \pm 0.41$ & $1.47 \pm 0.59 \mathrm{a}$ & $0.45 \pm 0.22 \mathrm{a}$ \\
Di்-S & $1.30 \pm 0.49$ & $1.61 \pm 0.73 \mathrm{a}$ & $0.69 \pm 0.34 \mathrm{a}$ \\
Kİ-S & $0.89 \pm 0.41$ & $1.23 \pm 0.64 \mathrm{a}$ & $0.18 \pm 0.13 \mathrm{a}$ \\
SKi் & $1.29 \pm 0.52 \mathrm{~b}$ & $2.54 \pm 0.98 \mathrm{~b} \mathrm{c}$ & $1.51 \pm 0.42 \mathrm{c}$
\end{tabular}

Veriler ortalama ve standart deviasyon olarak verilmiştir. $\mathrm{S}$ ve DY arası kıyaslamalarda "independent samples student-t testi" kullanılmıştır. DY ve DK arası kıyaslamalarda ise "paired samples student-t testi" kullanılmıştır. VKİ; Vücut Kitle İndeksi, OHI; Oral Hijyen İndeksi, SKI; Sulkus Kanama İndeksi.(a) OHİ-S, Dİ-S ve Kİ-S değerleri açısından, DY grubu ile DK grubu arasında istatistiksel anlamlı fark vardır ( $p<$ 0.05).(b) SKİ değerleri açısından, $S$ grubu ile DY grubu arasında istatistiksel anlamlı fark vardır $(p<0.05)$.(c) SKI değerleri açısından, DY grubu ile DK grubu arasında istatistiksel anlamlı fark vardır $(p<0.05)$.

"Süt Tüketimi", "Sebze Tüketimi", "Meyve Tüketimi", "Egzersiz" ve "Sakız Kullanımı" açısından gruplar arasında istatistiksel anlamlı fark izlenmedi (Sırasıla; $\mathrm{p}=0.164, \mathrm{p}=0.199, \mathrm{p}=0.325, \mathrm{p}=$ $0.099, p=0.762$ ) (Tablo 2).

"Öğün Atlama" açısından gruplar arasında istatistiksel anlamlı fark bulundu ( $p=0.001$ ). DK grubunda öğün atlama yapmayan bireylerin yüzdesi $S$ ve DY gruplarına göre daha yüksekti. S ve DY gruplarında ara sıra öğün atlama yüzdesi DK grubuna göre daha fazla bulundu. "Tatlı Tüketimi" açısından gruplar arasında istatistiksel anlamlı fark izlendi ( $p=$ 0.012). DY grubunda genellikle tatlı tüketen bireylerin

Tablo 2. Gruplara Göre Beslenme, Egzersiz Alışkanlıkları ve

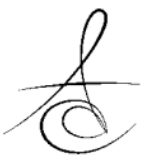


Ağız Hijyeni Anketi Sonuçları

\begin{tabular}{|c|c|c|c|c|}
\hline & & Gruplar & & \\
\hline & $\begin{array}{c}\text { Sağlıklı } \\
\text { Kontrol(S) }\end{array}$ & $\begin{array}{l}\text { T1DM Yeni } \\
\text { Teşhis (DY) }\end{array}$ & $\begin{array}{c}\text { T1DM } \\
\text { Kontrol(D } \\
\text { K) }\end{array}$ & $\mathbf{P}$ \\
\hline Öğün Atlama & & & & $0.001 \mathrm{a}$ \\
\hline Hiçbir Zaman & $13(43.3)$ & $13(43.3)$ & $27(90.0)$ & \\
\hline Ara Sira & $16(53.3)$ & $17(56.7)$ & $3(10.0)$ & \\
\hline Genellikle & $1(3.3)$ & $0(0.0)$ & $0(0.0)$ & \\
\hline Süt Tüketimi & & & & 0.164 \\
\hline Hiçbir Zaman & $3(10.0)$ & $0(0.0)$ & $0(0.0)$ & \\
\hline Ara Sıra & $14(46.7)$ & $16(53.3)$ & 14 (46.7) & \\
\hline Genellikle & $13(43.3)$ & $14(46.7)$ & $16(53.3)$ & \\
\hline Sebze Tüketimi & & & & 0.199 \\
\hline Hiçbir Zaman & $8(26.7)$ & $4(13.3)$ & $2(6.7)$ & \\
\hline Ara Sira & $13(43.3)$ & $17(56.7)$ & $14(46.7)$ & \\
\hline Genellikle & $9(30.0)$ & $9(30.0)$ & $14(46.7)$ & \\
\hline Meyve Tüketimi & & & & 0.325 \\
\hline Hiçbir Zaman & $8(26.7)$ & $5(16.7)$ & $2(6.7)$ & \\
\hline Ara Sira & $12(40.0)$ & $12(40.0)$ & $13(43.3)$ & \\
\hline Genellikle & $10(33.3)$ & $13(43.3)$ & $15(50.0)$ & \\
\hline Tatlı Tüketimi & & & & $0.012 \mathrm{~b}$ \\
\hline Hiçbir Zaman & $4(13.3)$ & $3(10.0)$ & $3(10.0)$ & \\
\hline Ara Sira & $13(43.3)$ & $7(23.3)$ & $20(66.7)$ & \\
\hline Genellikle & $13(43.3)$ & $20(66.7)$ & $7(23.3)$ & \\
\hline İçecek Tüketimi & & & & $0.002 c$ \\
\hline Hiçbir Zaman & $1(3.3)$ & $0(0.0)$ & $3(10.0)$ & \\
\hline Ara Sira & $19(63.3)$ & $7(23.3)$ & $17(56.7)$ & \\
\hline Genellikle & $10(33.3)$ & $23(76.7)$ & $10(33.3)$ & \\
\hline Atıştırmalık & & & & \\
\hline Tüketimi & & & & $0.0001 \mathrm{~d}$ \\
\hline Hiçbir Zaman & $4(13.3)$ & $0(0.0)$ & $1(3.3)$ & \\
\hline Ara Sira & $18(60.0)$ & $10(33.3)$ & $4(13.3)$ & \\
\hline Genellikle & $8(26.7)$ & $20(66.7)$ & $25(83.3)$ & \\
\hline Egzersiz & & & & 0.099 \\
\hline Hiçbir Zaman & $8(26.7)$ & $15(50.0)$ & $10(33.3)$ & \\
\hline Ara Sira & $18(60.0)$ & $14(46.7)$ & $13(43.3)$ & \\
\hline Genellikle & $4(13.3)$ & $1(3.3)$ & 7 (23.3) & \\
\hline Diş Fırçalama & & & & \\
\hline Sıklığı & & & & $0.002 \mathrm{e}$ \\
\hline Hiçbir Zaman & $6(20.0)$ & $11(36.7)$ & $0(0.0)$ & \\
\hline Ara Sira & $8(26.7)$ & $10(33.3)$ & $7(23.3)$ & \\
\hline Düzenli & $16(53.3)$ & $9(30.0)$ & $23(76.7)$ & \\
\hline Gargara & & & & \\
\hline Kullanımı & & & & $p=0.0001 \mathrm{f}$ \\
\hline Hiçbir Zaman & $18(60.0)$ & $11(36.7)$ & $5(16.7)$ & \\
\hline Ara Sıra & $4(13.3)$ & $16(53.3)$ & $11(36.7)$ & \\
\hline Düzenli & $8(26.7)$ & $3(10.0)$ & $14(46.7)$ & \\
\hline Sakız Kullanımı & & & & $p=0.762$ \\
\hline Hiçbir Zaman & $10(33.3)$ & $10(33.3)$ & $14(46.7)$ & \\
\hline Ara Sira & $11(36.7)$ & $12(40.0)$ & $8(26.7)$ & \\
\hline Düzenli & $9(30.0)$ & $8(26.7)$ & $8(26.7)$ & \\
\hline Diş Hekimini & & & & \\
\hline $\begin{array}{l}\text { Ziyaret Etme } \\
\text { Sıklığı }\end{array}$ & & & & $0.0001 \mathrm{~g}$ \\
\hline Hiçbir Zaman & $0(0.0)$ & $9(30.0)$ & & \\
\hline Ara Sira & $13(43.3)$ & $16(53.3)$ & - & \\
\hline Düzenli & $17(56.7)$ & $5(16.7)$ & & \\
\hline Diş Yüzeyi & & & & \\
\hline Temizliği Sıklığı & & & & 0.235 \\
\hline Hiçbir Zaman & $10(33.3)$ & $16(53.3)$ & & \\
\hline Ara Sira & $12(40.0)$ & $10(33.3)$ & - & \\
\hline Düzenli & $8(26.7)$ & $4(13.3)$ & & \\
\hline Fırçalama & & & & \\
\hline Esnasında Dişeti & & & & \\
\hline Kanaması & & & & $0.017 \mathrm{~h}$ \\
\hline Hikâyesi & & & & \\
\hline Yok & $12(40.0)$ & $4(13.3)$ & $6(20.0)$ & \\
\hline Ara Sira & $10(33.3)$ & $10(33.3)$ & $17(56.7)$ & \\
\hline Genellikle & $8(26.7)$ & $16(53.3)$ & $7(23.3)$ & \\
\hline
\end{tabular}

Veriler sayı ve (yüzde) olarak verilmiştir. Gruplar arası kıyaslamalarda $x^{2}$ testi kullanılmıştır.(a)"Öğün Atlama" açısından gruplar arasında istatistiksel anlamlı fark vardır $(p<0.05)$. (b)"Tatlı Tüketimi" açısından gruplar arasında istatistiksel anlamlı fark vardır ( $\mathrm{p}<0.05)$.(c) "İçecek Tüketimi" açısından gruplar arasında istatistiksel anlamlı fark vardır $(p<0.05)$. (d) "Atıştırmalık Tüketimi" açısından gruplar arasında istatistiksel anlamlı fark vardır $(p<0.05)$. (e)"Diş Fırçalama Sıklığı" açısından gruplar arasında istatistiksel anlamlı fark vardır $(\mathrm{p}<0.05)$. (f)"Gargara Kullanımı" açısından gruplar arasında istatistiksel anlamlı fark vardır $(p<0.05)$. (g) "Diş Hekimini Ziyaret Etme Sıklığı" açısından gruplar arasında istatistiksel anlamlı fark vardır $(p<0.05)$.(h)"Fırçalama Esnasında Dişeti Kanaması Hikâyesi" açısından gruplar arasında istatistiksel anlamlı fark vardır ( $p<0.05)$

yüzdesi S ve DK gruplarına göre daha yüksekti. "İçecek Tüketimi" açısından gruplar arasında istatistik- sel anlamlı fark vardı $(p=0.002)$. DY grubunda genellikle içecek tüketen bireylerin yüzdesi $S$ ve DK gruplarına göre daha fazlaydı. "Atıştırmalık Tüketimi" açısından gruplar arasında istatistiksel anlamlı fark bulundu ( $p=$ 0.0001). S grubunda genellikle atıştırmalık tüketen bireylerin yüzdesi DY ve DK gruplarına göre daha azdı (Tablo 2).

"Diş Fırçalama Sıklığı" açısından gruplar arasın$d a$ istatistiksel anlamlı fark izlendi $(p=0.002)$. DK grubunda genellikle dişlerini fırçalayan bireylerin yüzdesi $S$ ve DY gruplarına göre daha fazlaydı. "Gargara Kullanımı" açısından gruplar arasında istatistiksel anlamlı fark bulundu ( $p=0.0001)$. DK grubunda genellikle gargara yapan bireylerin yüzdesi $S$ ve DY gruplarına göre daha fazlaydı. S grubundaki hiçbir zaman gargara yapmayan bireylerin yüzdesi DY ve DK gruplarına göre daha yüksekti. "Diş Hekimini Ziyaret Etme Sıklığı" açısından gruplar arasında istatistiksel anlamlı fark vardı $(p=0.0001)$. DY grubunda henüz diş hekimine gitmemiş bireylerin yüzdesi $S$ grubuna göre daha fazlaydı. S grubunda düzenli diş hekimine giden bireylerin yüzdesi DY grubuna göre daha yüksekti. "Diş Yüzeyi Temizliği Sıklığı" açısından grup- lar arasında istatistiksel anlamlı fark bulunmadı $(p=0.235)$. "Fırçalama Esnasında Dişeti Kanaması Hikâyesi" açısından gruplar arasında istatistiksel anlamlı fark vardı $(p=$ 0.0017). S grubunda fırçalama esnasında dişeti kanaması olmayan bireylerin yüzdesi DY ve DK gruplarına göre daha yüksekti. DY grubunda fırçalama esnasında genellikle dişeti kanaması olan bireylerin yüzdesi $S$ ve DK gruplarına göre daha fazlaydı (Tablo 2).

\section{TARTIŞMA}

Periodontitis; periodontal cep formasyonu, klinik ataşman kaybı ve kemik yıkımıyla karakterize en yaygın görülen inflamatuar hastalıklardan birisidir. Diabetes Mellitus gibi sistemik hastalıklar periodontal dokuları etkilemekte ve periodontal hastalığın şiddetlenmesine sebep olabilmektedir. ${ }^{19}$ Periodontal hastaIıkların da insülin direncini ve glisemik kontrolü bozarak sistemik etki gösterdiği ve diyabetin kontrolünü zorlaştırdığı bilinmektedir. ${ }^{20}$ İki hastalık arasındaki bu çift yönlü ilişki, her iki hastalığın da birlikte kontrol edilmesinin önemini ortaya koymaktadır. Dolayısı ile diyabetik kontrol kadar periodontal durumun da ciddiye alınması zorunludur. ${ }^{21}$

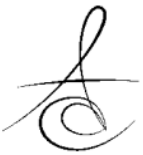


Çalışmamızın sonuçları değerlendirildiğinde; OHİ-S, Dİ-S ve Kİ-S değerleri açısından, $\mathrm{S}$ grubu ile DY grubu arasında istatistiksel anlamlı fark bulunmadı (Sırasıyla; $p=0.107, p=0.075, p=0.122$ ). DY grubu ile DK grubu arasında ise istatistiksel anlamlı fark izlendi (Sırasıyla; $p=0.0050, p=0.0013, p=0.0001$ ). DK grubunda OHİ-S değerlerinin azalması, diyabetli hastalarda ağız hijyeni eğitiminin etkili olduğunu düşündürmektedir. Literatürde tip 1 diyabetli çocuk ve adolesanlarda oral hijyeni değerlendiren çalışmalar mevcuttur. ${ }^{22}$ Fakat diyabetik bireylere verilen oral hijyen eğitiminin etkisini değerlendiren çalışma literatürde bulunmamaktadır. Alves ve arkadaşlarının ${ }^{23}$ tip 1 diyabetli bireylerin oral hijyen alışkanlıklarının ve düzenli diş hekimi kontrollerinin, sağlıklı kontrollere göre daha düzenli olduğunu göstermişlerdir. Dolayısı ile diyabetli hastalara verilen eğitimin sonucu olarak, diyabetiklerin genel sağlıklarına verdikleri önemin arttığı ve ağız hijyenine yönelik farkındalıklarının yükseldiği sonucuna varılabilir.

Çalışmamızda, SKİ değerleri açısından, S grubu ile DY grubu arasında ve DY grubu ile DK grubu arasında istatistiksel anlamlı fark bulundu (Sırasıyla; $p=$ $0.002, p=0.015$ ) (Tablo 1). Tip 1 diyabetli bireylerde oral hijyen alışkanlıkları bıraktıılarak deneysel gingivitis oluşturulmasının, plak birikim miktarından bağımSIZ olarak, dişeti oluğu sIvısında inflamatuar biyomarker seviyelerinin sağlıkı bireylere göre daha fazla arttığı gösterilmiştir. ${ }^{24}$ Ayrıca Tip 1 diyabet teşhisi ile izlenen çocukların plak ve gingival indeks değerlerinin yüksek olduğu ve sıkı dental kontrollerle takibi önerilmiştir. ${ }^{9-13}$

İlaç tedavisi ve besin alımını dengeleyerek kan glikoz düzeyini düzenlemek ve vücut ağırlığını normalleştirmek diyabetli bireylerde beslenme tedavisinin amaçları arasındadır. Diyabette beslenme eğitimi; diyabetik bir bireyin, diyabetin akut ve kronik komplikasyonlarından korunması, glisemik kontrolü sağlayabilmesi ve kaliteli bir yaşam sürebilmesi için son derece önemlidir. Beslenme eğitiminde teorik bilgilerin verilmesinin yanı sıra uygun beslenme alışkanlığının yaşam şekli haline gelmesi de sağlanmalıdır. Bunu sağlamanın en önemli yolu da bireyin eğitim sonrası takibidir. Çocuğun ebeveyni/ bakıcısı ve okul öğretmenlerinin eğitimi, çocuğun izlenmesi, çocuk ve aileye destek uzun dönem diyabetin kontrolünde önemlidir. ${ }^{25}$ Diyabetli çocukların beslenmesi, diyabetli olmayan yaşıtları ile aynıdır ve tamamen sağıkılı beslenme ilkeleri- ne dayanır. Günlük beslenmede yer verilmeyen, ancak çocuklar tarafından çok sevilen şekerin günlük enerjinin sadece \%10' u kadar olması ve bu oranı aşımamaSı gerekmektedir. ${ }^{26} \mathrm{Bu}$ oranın üstünde tüketilen şekerin, sağıklı çocuklarda olduğu gibi diyabetlilerde de beslenme kalitesini düşürdüğü, obeziteye ${ }^{27}$ ve diş çürüklerine ve erozyona neden olduğu bilinmektedir. ${ }^{28,} 30$

Çalışmamızın sonuçları değerlendirildiğinde; beslenme ve egzersiz anketi sonuçlarına göre süt, sebze, meyve tüketimi ve egzersiz açısından gruplar arasında istatistiksel anlamlı farklılık bulunmadı ( $p>$ 0.05). Fakat öğün atlama, tatlı, içecek, atıştırmalık tüketimi açısından gruplar arasında istatistiksel anlamlı fark izlendi $(p<0.05)$ (Tablo 2).

Çalışmamızda; DK grubunda öğün atlamayan bireylerin yüzdesi (\%90), S (\%43.3) ve DY (\%43.3) gruplarına göre daha yüksekti (Tablo 2). Bu bulgunun sebebi, T1DM hastalarında yapılan beslenme eğitiminin bir sonucu olduğu düşünülmektedir. Çünkü ara sıra öğün atlayan DY hastalarının oranı \%56.7 iken, DK grubunda bu oran \%10'a gerilediği, aynı zamanda DY grubunda öğün atlamayan bireylerin oranı \%43.3 iken, DK grubunda bu oranın \%90'a yükseldiği izlendi. Dolayısı ile beslenme eğitiminin diyabet hastalarında öğün atlama alışkanlığını anlamlı bir şekilde azalttığı düşünülebilir. Çünkü beslenme eğitiminde olası bir hipoglisemi ve hiperglisemiyi engellemek amacıyla diyabetli bireylere öğün atlamamaları, ayrıca gerektiğinde ara öğün almaları önerilmektedir. ${ }^{31}$

Araştırmamızda; DY grubunda genellikle tatlı tüketen bireylerin yüzdesi (\%66.7), S (\%43.3) ve DK (\%23.3) gruplarına göre daha yüksekti (Tablo 2). Bu bulgunun sebebi, DY grubundaki bireylerin kontrolsüz diyabete bağlı polifaji semptomları göstermelerine bağlı olabilir. Semptomlarını bastırmak amacıyla kontrolsüz diyabetli bireylerin tatı tükettikleri, diyabet kontrollü hale geldikten sonra ise tatlı tüketiminin düştüğü izlenmektedir.

Çalışmamızda; DY grubunda genellikle içecek tüketen bireylerin yüzdesi (\%76.7), S ve DK gruplarına göre (\%33.3) daha fazlaydı (Tablo 2). Bu bulgunun sebebi, DY grubundaki bireylerin kontrolsüz diyabete bağlı polidipsi semptomları göstermelerine bağı olabilir. Dolayısı ile kontrolsüz diyabette artan içecek tüketimi intiyacının, diyabet kontrollü hale geçtikten sonra azaldığı izlenmektedir.

Araştırmamızda; S grubunda genellikle atıştırmalık tüketen bireylerin yüzdesi (\%26.7), DY (\%66.7) 
ve DK (\%83.3) gruplarına göre daha azdı (Tablo 2). Diyabet gruplarında atıştırmalık tüketiminin artmasının sebebinin, DY grubundaki bireylerin kontrolsüz diyabete bağlı polidipsi ve polifaji semptomları göstermelerine, DK grubunda ise olası bir hipoglisemi ve hiperglisemiyi engellemek amacıyla bireylerin öğün sayılarını artırmalarına bağlı olduğunu düşünmekteyiz.

Özetle, çalışmamızdaki kontrolsüz diyabetik bireylerde tatlı tüketimi ve diyabet kontrollü hale alındıktan sonra ise atıştırmalık tüketiminde artış izlendi. Dolayısı ile diyabetik hastalarda sağlıklı kontrollere göre tatlı tüketiminin ve öğün sayılarının artışı, diş hekimlerini diyabetik hastaların oral hijyen alışkanlıklarını değiştirmeye itebilir. Sık beslenen diyabetik bireylerde plak indeksinde zamanla artış izleniyorsa, diş fırçalama sayısı artırılarak plak indeksinin düşürülmesi ve ileride gelişebilecek dental ve periodontal problemlerin önlenmesi düşünülebilir.

Çalışmamızın ağız hijyeni anketi sonuçlarını değerlendirdiğimizde; diş fırçalama sıklığı, gargara kullanımı, diş hekimini ziyaret etme sıklığı ve fırçalama esnasında dişeti kanaması hikâyesi açısından gruplar arasında istatistiksel anlamlı fark vardı ( $p<0.05$ ). Sakız kullanımı ve diş yüzeyi temizliği sıklığı açısından ise gruplar arasında anlamlı fark bulunmadı ( $p>0.05$ ).

Çalışmamızda; hiçbir zaman dişlerini fırçalamayan bireylerin yüzdesi S grubunda \%20, DY grubunda $\% 36.7$, DK grubunda ise $\% 0$ olarak izlendi. DK grubunda genellikle dişlerini fırçalayan bireylerin yüzdesi (\%76.7), S (\%53.3) ve DY (\%30) gruplarına göre daha yüksekti (Tablo 2). Hiçbir zaman dişlerini fırçalamayan bireylerin yüzdesinin DY grubuna göre DK grubunda azaldığı izlendi. Genellikle dişlerini fırçala- yan bireylerin yüzdesinin ise DY grubuna göre DK grubunda yükseldiği görüldü. Bu bulguların sebebi, diyabet teşhisi konulduktan sonra hastalara ve ebeveynlere oral hijyen eğitimi verilmesi ve periodontal tedaviye ihtiyacı olan bireylere diş yüzeyi temizliği yapılması sonrası bireylerin diş fırçalama sıklığını artırması olabilir.

Araştırmamızda; DK grubunda düzenli gargara yapan bireylerin yüzdesi (\%46.7), S (\%26.7) ve DY (\%10) gruplarına göre daha yüksekti. S grubunda hiçbir zaman gargara yapmayan bireylerin yüzdesi (\%60), DY (\%36.7) ve DK (\%16.7) gruplarına göre daha fazlaydı (Tablo 2). DK grubunda düzenli gargara yapan bireylerin yüzdesinin DY grubuna göre daha yüksek olması, diyabetik hastaların oral hijyen eğitimi sonrası gargara yapma intiyaçlarının farkındalıklarının artışına bağlı olduğunu düşündürmektedir. Çünkü fırçalama esnasında dişeti kanaması olan ve fırçalamaya rağmen kanaması geçmeyen hastalara ek olarak Klorheksidin diglukonat ile gargara yapması ve hekimine başvurması önerilmiştir. ${ }^{32}$ Diyabetik gruplarda fırçalama esnasında dişeti kanaması hikâyesi olan hastaların yüzdelerinin sağlıklı gruba göre yüksek olması, bu düşüncemizi desteklemektedir.

Çalışmamızda; DY grubunda henüz diş hekimine gitmemiş bireylerin yüzdesi (\%30), S (\%0) grubuna göre daha fazlaydı. S grubunda düzenli diş hekimine giden bireylerin yüzdesi (\%56.7), DY grubuna göre (\%16.7) daha yüksekti (Tablo 2). İki grup arasındaki bu farkın nedeni, sağlıklı hasta grubunun üniversitemize tedavi amacıyla başvuran hasta grubundan, dolayısıyla zaten tedavi intiyacı olan hastalardan seçilmiş olmasından kaynaklandığını düşünmekteyiz. Dolayısı ile diyabeti olan hasta grubunun diş hekimini düzenli ziyaret etmediği sonu-cuna varamayız, fakat diyabetik hastaların genel eğitiminde ve oral hijyen motivasyonu sırasında düzenli diş hekimi kontrollerine gitmelerinin vurgulanmasının önemli olduğunu düşünmekteyiz.

Araştırmamızda; S grubunda fırçalama esnasında dişeti kanaması olmayan bireylerin yüzdesi (\%40), DY (\%13.3) ve DK (\%20) gruplarına göre daha fazlaydı. DY grubunda fırçalama esnasında genellikle dişeti kanaması olan bireylerin yüzdesi (\%53.3), S (\%26.7) ve DK (\%23.3) gruplarına göre daha yüksekti (Tablo 2). DY grubunda fırçalama esnasında dişeti kanaması hikâyesinin S ve DK grubuna göre daha yüksek olması, kontrolsüz diyabete bağlı görülebilecek gingival inflamasyona bağlı olabilir. ${ }^{11}$

Çalışma gruplarının oluşturulmasındaki farklılık, çalışmamızın bir limitasyonudur. Sağlıklı kontrol grubu diş hekimliği fakültesine tedavi amacı ile başvuran gönüllü bireylerden oluşturulmuştur. Diğer grup ise diyabet nedeniyle hastaneye başvuran ve dental tedavi talebi olmayan bireylerden oluşmaktadır. Bu iki grubun oral hijyen alışkanlıklarının farklı olması doğaldır. Ayrıca fırçalama esnasında dişeti kanaması hikâyesi gibi belirteçlerin DY grubunda daha yüksek olması kontrolsüz diyabetle ilişkili gingival inflamasyona bağlı olabileceği gibi hatalı örneklem seçimine de bağlı olabilir. İleriki çalışmalarda sağlıklı kontrol grubunun diş hekimliği fakültesine tedavi intiyacı ile başvuran hastalardan değil de farklı gruplardan seçilmesi ve elde edilecek verilerin literatürdeki araştırmalar ve çalışmamızın bulguları ile karşılaştırılması faydalı olacaktır.

Kunzel ve arkadaşları; ${ }^{33}$ diş hekimlerinin diyabetli hastalara müdahale konusunda bilgilerine çok güvenmediklerini, diyabetin teşhisinde aktif rol oyna-

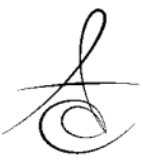


dıklarını düşünmediklerini; hastaların ve diğer meslektaşlarının da kendilerinden böyle bir beklentide olmadıklarını bildirmektedir. İnsülin tedavisindeki gelişmeler tip 1 diyabetli bireylerin yaşam süresini uzatmakta ve diş hekimlerinin de tip 1 diyabetli bireylerle karşılaşma olasılığı giderek artmaktadır. Bu nedenle diş hekimleri tarafından tip 1 diyabetin komplikasyonlarının, risk faktörlerinin ve olası tanı/tedavi yöntemlerinin değerlendirilmesi önem taşımaktadır.

Diyabetin ağız içi komplikasyonları ve diş hekimliğini ilgilendiren özellikleriyle ilgili çalışmaların pek çoğu periodontal hastalıklar üzerinde yoğunlaşsa da; ${ }^{21}$ diş çürükleri, ${ }^{34}$ tükürük bezi disfonksiyonları, ${ }^{35}$ oral mukozal hastalıklar ve parakanseröz lezyonlar, ${ }^{36,37}$ kandida enfeksiyonları ${ }^{38}$ ve tat alma bozuklukları ${ }^{39}$ ile ilgisini bildiren çalışmalar da mevcuttur. Yapılan çalışmalara göre diyabetli hastaların yaklaşık \%30'unun hastalığından haberdar olmadığı bildirilmektedir. ${ }^{40} \mathrm{Bu}$ nedenle, ağız içi bulguların henüz tanı konmamış ya da yetersiz metabolik kontrole sahip tip 1 diyabetli bir bireye ait olabileceği unutulmamalıdır.

\section{TEŞEKKÜRLER}

Bu araştırmayı destekleyen TÜBİTAK'a teşekkürlerimizi sunarız (Proje No: 114S004).

\section{KAYNAKLAR}

1. Kidambi $S$, Patel SB. Diabetes mellitus: considerations for dentistry. J Am Dent Assoc 2008;(Suppl 139):8-18.

2. Lalla E, Papapanou PN. Diabetes mellitus and periodontitis: a tale of two common interrelated diseases. Nat Rev Endocrinol 2011;7:738-48.

3. Taylor JJ, Preshaw PM, Lalla E. A review of the evidence for pathogenic mechanisms that may link periodontitis and diabetes. J Periodontol 2013;84:113-34.

4. Liu R, Bal HS, Desta T, Krothapalli N, Alyassi M, Luan $Q$, et al. Diabetes enhances periodontal bone loss through enhanced resorption and diminished bone formation. J Dent Res 2006;85:510-4.

5. Graves DT, Liu R, Alikhani M, Al-Mashat $H$, Trackman PC. Diabetes-enhanced inflammation and apoptosis--impact on periodontal pathology. ] Dent Res 2006;85:15-21.

6. Mishima N, Sahara N, Shirakawa M, Ozawa H. Effect of streptozotocin-induced diabetes mellitus on alveolar bone deposition in the rat. Arch Oral Biol 2002;47:843-9.

7. Needleman I, Suvan J, Moles DR, Pimlott J. A systematic review of professional mechanical plaque removal for prevention of periodontal diseases. J Clin Periodontol 2005;(Suppl 32)6:22982.

8. Özer Ö, Demiralp D. Periodontitis kardiyovasküler hastalığa neden olur mu? Atatürk Üniv Diş Hek Fak Derg 2005;15:62-70.

9. Gujjar KR, Khadija $H$, Suleiman MO, Amith HV. Gingival health status of 2- to 15-year-old Benghazi children with type-I diabetes mellitus. J Dent Child (Chic) 2011;78:96-101.

10. Orbak R, Simsek S, Orbak Z, Kavrut F, Colak M. The influence of type- 1 diabetes mellitus on dentition and oral health in children and adolescents. Yonsei Med J 2008;49:357-65.

11. Lal S, Cheng B, Kaplan S, Softness B, Greenberg E, Goland RS, et al. Gingival bleeding in 6- to 13year-old children with diabetes mellitus. Pediatr Dent 2007;29:426-30.

12. Karjalainen KM, Knuuttila ML. The onset of diabetes and poor metabolic control increases gingival bleeding in children and adolescents with insulin-dependent diabetes mellitus. J Clin Periodontol 1996;23:1060-7.

13. Siudikiene J, Maciulskiene V, Dobrovolskiene R, Nedzelskiene I. Oral hygiene in children with type I diabetes mellitus. Stomatologija 2005;7:24-7.

14. Merchant AT, Oranbandid S, Jethwani M, Choi YH, Morrato EH, Pitiphat $W$, et al. Oral care practices and A1C among youth with type 1 and type 2 diabetes. J Periodontol 2012;83:856-63.

15. Kleemola-Kujala E, Rasanen L. Relationship of oral hygiene and sugar consumption to risk of caries in children. Community Dent Oral Epidemiol 1982;10:224-33.

16. Bawadi HA, Khader YS, Haroun TF, Al-Omari M, Tayyem RF. The association between periodontal disease, physical activity and healthy diet among adults in Jordan. J Periodontal Res 2011;46:74-81.

17. Gillies CL, Abrams KR, Lambert PC, Cooper NJ, Sutton AJ, Hsu RT, et al. Pharmacological and lifestyle interventions to prevent or delay type 2 diabetes in people with impaired glucose tolerance: systematic review and meta-analysis. BMJ 2007;334:299.

18. Newbrun E. Indices to measure gingival bleeding. J Periodontol 1996;67:555-61.

19. Taylor GW, Manz MC, Borgnakke WS. Diabetes, periodontal diseases, dental caries, and tooth loss: a review of the literature. Compend Contin Educ

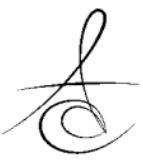


Dent 2004;25:179-84.

20. Stanko P, Izakovicova Holla L. Bidirectional association between diabetes mellitus and inflammatory periodontal disease. A review. Biomed Pap Med Fac Univ Palacky Olomouc Czech Repub 2014;158:35-8.

21. Ismail $A F$, McGrath $C P$, Yiu CK. Oral health of children with type 1 diabetes mellitus: A systematic review. Diabetes Res Clin Pract 2015;108:369-81.

22. Carneiro VL, Fraiz FC, Ferreira Fde M, Pintarelli TP, Oliveira AC, Boguszewski MC. The influence of glycemic control on the oral health of children and adolescents with diabetes mellitus type 1 . Arch Endocrinol Metab 2015;59:535-40.

23. Alves C, Brandao M, Andion J, Menezes R. Oral health knowledge and habits in children with type 1 diabetes mellitus. Braz Dent J 2009;20:70-3.

24. Salvi GE, Franco LM, Braun TM, Lee A, Rutger Persson G, Lang NP, et al. Pro-inflammatory biomarkers during experimental gingivitis in patients with type 1 diabetes mellitus: a proof-ofconcept study. J Clin Periodontol 2010;37:9-16.

25. Overby NC, Margeirsdottir HD, Brunborg C, DahlJorgensen K, Andersen LF. Sweets, snacking habits, and skipping meals in children and adolescents on intensive insulin treatment. Pediatr Diabetes 2008;9:393-400.

26. Rickard KA, Loghmani ES, Cleveland JL, Fineberg NS, Freidenberg GR. Lower glycemic response to sucrose in the diets of children with type 1 diabetes. J Pediatr 1998;133:429-34.

27. Walker CG, Zariwala MG, Holness MJ, Sugden MC. Diet, obesity and diabetes: a current update. Clin Sci (Lond) 2007;112:93-111.

28. Siudikiene J, Maciulskiene V, Nedzelskiene I. Dietary and oral hygiene habits in children with type I diabetes mellitus related to dental caries. Stomatologija 2005;7:58-62.

29. Yetiş CÇ, Kırzıoğlu Z. Çocuklarda dental erozyon ve koruyucu uygulamalar. Atatürk Üniv Diş Hek Fak Derg 2015:81-90.

30. Kara M, Gürbüz E, Mete A, Şahin T, Çelik Ç, Yamanel K. Diş Hekimliği Fakültesi Öğrencilerinde Beslenme Alışkanlıkları ve Ağız-Diş Sağlığı İlişkisi. Atatürk Üniv Diş Hek Fak Derg 2009;19:161-7.

31. Campbell MD, Walker M, Trenell MI, Stevenson EJ, Turner D, Bracken RM, et al. A low-glycemic index meal and bedtime snack prevents postprandial hyperglycemia and associated rises in inflammatory markers, providing protection from early but not late nocturnal hypoglycemia following evening exercise in type 1 diabetes. Diabetes Care 2014;37:1845-53.

32. Walsh TF, Unsal E, Davis LG, Yilmaz O. The effect of irrigation with chlorhexidine or saline on plaque vitality. J Clin Periodontol 1995;22:262-4.

33. Kunzel C, Lalla E, Albert DA, Yin H, Lamster IB. On the primary care frontlines: the role of the general practitioner in smoking-cessation activities and diabetes management. J Am Dent Assoc 2005; 136:1144-53.

34. Sampaio N, Mello S, Alves C. Dental cariesassociated risk factors and type 1 diabetes mellitus. Pediatr Endocrinol Diabetes Metab 2011;17:152-7.

35. Aitken-Saavedra J, Rojas-Alcayaga G, MaturanaRamirez A, Escobar-Alvarez A, Cortes-Coloma A, Reyes-Rojas $M$, et al. Salivary gland dysfunction markers in type 2 diabetes mellitus patients. J Clin Exp Dent 2015;7:501-5.

36. Silva MF, Barbosa KG, Pereira JV, Bento PM, Godoy GP, Gomes DQ. Prevalence of oral mucosal lesions among patients with diabetes mellitus types 1 and 2. An Bras Dermatol 2015;90:49-53.

37. Saini R, Al-Maweri SA, Saini $D$, Ismail NM, Ismail AR. Oral mucosal lesions in non oral habit diabetic patients and association of diabetes mellitus with oral precancerous lesions. Diabetes Res Clin Pract 2010;89:320-6.

38. Guggenheimer J, Moore PA, Rossie K, Myers D, Mongelluzzo MB, Block $\mathrm{HM}$, et al. Insulindependent diabetes mellitus and oral soft tissue pathologies: II. Prevalence and characteristics of Candida and Candidal lesions. Oral Surg Oral Med Oral Pathol Oral Radiol Endod 2000;89:570-6.

39. Naka A, Riedl M, Luger $A$, Hummel T, Mueller CA. Clinical significance of smell and taste disorders in patients with diabetes mellitus. Eur Arch Otorhinolaryngol 2010;267:547-50.

40. Lamster IB, Lalla E, Borgnakke WS, Taylor GW. The relationship between oral health and diabetes mellitus. J Am Dent Assoc 2008;(Suppl 139):19-24.

\section{Yazışma Adresi}

Dr. Dt. Cüneyt Asım ARAL

Malatya Ağız ve Diş Sağlığı Hastanesi, Periodontoloji Uzmanı, Yeşilyurt, Malatya.

GSM: 05424577657

e-mail: cuneytasimaral@gmail.com 